\title{
A case of immune-mediated type 1 diabetes mellitus due to congenital rubella infection
}

\author{
Hüseyin Anıl Korkmaz, MD', \\ Çağatay Ermiş, MD²
}

${ }^{1}$ Division of of Pediatric Endocrinology, Balıkesir Atatürk State Hospital, Balıkesir, Turkey

${ }^{2}$ Child and Adolescent Psychiatry Unit, Dokuz Eylul University Hospital, Izmir Turkey

\begin{abstract}
Congenital rubella infection is a transplacental infection that can cause intrauterine growth retardation, cataracts, patent ductus arteriosus, hearing loss, microcephaly, thrombocytopenia, and severe fetal injury. It has been shown that type 1 diabetes mellitus develops in $12 \%-20 \%$ of patients with congenital rubella infection, and disorders in the oral glucose tolerance test is observed in $40 \%$ of patients. No biochemical or serological markers exist which could indicate that type 1 diabetes was caused by a congenital rubella infection. We report a 13-year-old male patient who was admitted to our hospital with complaints of new-onset polyuria, polydipsia, urination, and weight loss. In addition, he was found to have neurosensory hearing loss, patent ductus arteriosus, and microcephaly. Immunemediated type 1 diabetes mellitus was considered due to the fact that the autoantibodies of diabetes mellitus were positive.
\end{abstract}

Keywords: Rubella, Diabetes, Hearing loss

\section{Introduction}

While rubella can lead to a mild clinical picture in children and adults, it can affect all organs and systems of the fetus in pregnancy. If women have rubella infection in the first 3-4 months of pregnancy, the virus is usually transmitted to the fetus and results in spontaneous abortion, stillbirth, or congenital rubella syndrome. ${ }^{1-3)}$ Congenital rubella infection is a transplacental infection that can cause intrauterine growth retardation, cataracts, patent ductus arteriosus, hearing loss, microcephaly, thrombocytopenia, and severe fetal injury. ${ }^{1,2)}$ Although the rubella virus is known to infect pancreatic beta cells, the etiological role of this viral infection in the development of type 1 diabetes mellitus (DM) in humans is still unknown. ${ }^{4)}$ It has been shown that type $1 \mathrm{DM}$ develops in $12 \%-20 \%$ of patients with congenital rubella infection, and disorders in the oral glucose tolerance test is observed in $40 \%$ of patients with congenital rubella infection. ${ }^{5,6)}$ This article describes a case of immune-mediated type 1 DM in a male patient with congenital neurosensory hearing loss, microcephaly, and patent ductus arteriosus that was thought to be associated with congenital rubella infection.

\section{Case report}

A 13-year-old male patient presented with complaints of new-onset polydipsia, excessive urination, and weight loss. The patient stated he had lost $7 \mathrm{~kg}$ over a period of 2 months. His past medical history included neurosensory hearing loss from birth and patent ductus arteriosus that was discovered at three months of age in the Pediatric Cardiology Department. He had no response to voice warnings at 3 months of age, and his neurosensory hearing loss was diagnosed with an auditory brainstem evoked responses test. In addition, the patient was followed by the Child and Adolescent Psychiatry Department due to behavioral problems and learning disabilities; he had been diagnosed with autistic spectrum disorder. There was
Hüseyin Anıl Korkmaz, MD

Division of of Pediatric Endocrinology, Balıkesir Atatürk State Hospital, Yıldız Mahallesi, Soma Caddesi, Merkez, 10020 Balıkesir, Turkey

Tel: +90-226-221-3510

Fax: +90-226-221-3516

E-mail: hanilkorkmaz@gmail.com

https://orcid.org/0000-0001-58009014
ISSN: 2287-1012(Print)

This is an Open Access article distributed under the terms of the Creative Commons Attribution Non-Commercial License (http:// creativecommons.org/licenses/by-nc/4.0) which permits unrestricted non-commercial use, distribution, and reproduction in any medium, provided the original work is properly cited.
ISSN: 2287-129210nline 
no kinship between his parents. The patient's mother had a fever and a red rash on her face during the second trimester of pregnancy, although she was not diagnosed with rubella infection at that time.

On physical examination, the patient's weight was 42.7 $\mathrm{kg}$ (25th-50th percentile), height was $153.2 \mathrm{~cm}$ (25th-50th percentile), and his head circumference was $46 \mathrm{~cm}(<3 \mathrm{rd}$ percentile). A 2/6 cardiac murmur and hearing aid were noted. Laboratory examinations revealed blood glucose was $619 \mathrm{mg} /$ $\mathrm{dL}$, urine ketone was +3 , blood gas showed metabolic acidosis ( $\mathrm{pH}, 6.92 ; \mathrm{HCO}_{3}, 4 \mathrm{mEq} / \mathrm{L} ; \mathrm{PaCO}_{2}, 24 \mathrm{mmHg}$ ), insulin was 4.1 $\mathrm{IU} / \mathrm{mL}$ (range, $2-18 \mathrm{IU} / \mathrm{mL}$ ), and serum C-peptide level was $1.23 \mathrm{ng} / \mathrm{mL}$ (range, $1.1-4.4 \mathrm{ng} / \mathrm{mL}$ ). The patient's glycosylated hemoglobin value was $15.9 \%$, anti-insulin antibody was $0.78 \mathrm{U} /$ $\mathrm{mL}$ (range, $0-0.5 \mathrm{U})$, anti-GAD was $22.8 \mathrm{U} / \mathrm{mL}(<1 \mathrm{U} / \mathrm{mL})$, and the islet cell antibody was positive. Orbital magnetic resonance imaging demonstrated no optic atrophy and normal optic nerve thickness, so Wolfram syndrome was excluded. In addition, genetic analysis for Wolfram's syndrome was normal.

The patient was diagnosed with immune-mediated type I $\mathrm{DM}$, and intravenous fluid and insulin therapy were started according to the degree of dehydration. After the patient's metabolic acidity was corrected and blood glucose regulation was achieved, his medication was switched to subcutaneous insulin therapy 1.2 units $/ \mathrm{kg} /$ day. Considering the patient's patent ductus arteriosus, microcephaly, and neurosensory hearing loss, his immune-mediated type 1 diabetes was thought to be associated with a congenital rubella infection following his mother's febrile rash illness during pregnancy.

\section{Discussion}

In this article, we present the case of a 13-year-old male with congenital neurosensory hearing loss, patent ductus arteriosus, and type 1 diabetes that was thought to be associated with a congenital rubella infection following his mother's prenatal fever and red rash disease. Wolfram syndrome has been described as a clinical condition in which DIDMOAD (diabetes insipidus, diabetes mellitus, optic atrophy, and deafness) coexist. $\left.{ }^{7.8}\right)$ There is a significant difference between DM associated with Wolfram syndrome and autoimmune type 1 diabetes: DM associated with Wolfram syndrome is accompanied by a decrease in the number and function of pancreatic $\beta$-cells, and Wolfram patients have no autoimmune diabetes autoantibodies (which are associated with an autoimmune process). ${ }^{9)}$ In the present case, the immunodiagnostic autoantibodies were found to be positive during the period when diabetes was diagnosed. Although the patient's hearing loss and diabetes suggested Wolfram syndrome, he had was no optic atrophy in either eye on the retinal examination and the optic nerve thickness was normal bilaterally on orbital MR. Finally, Wolfram syndrome was ruled out by a normal genetic analysis that was submitted for Wolfram syndrome. DM related to mitochondrial diseases was excluded for the following reasons: detection of diabetes autoantibodies, lack of family history suggesting hereditary mitochondrial diabetes, normal retinal examination, and absence of clinical findings suggestive of endocrine dysfunction, neuromuscular disease or central nervous system disease, all of which are associated with a mitochondrial disease. Recently, GATA6 mutations have been associated with severe congenital heart disease and neonatal/childhood-onset diabetes. ${ }^{10)}$ Our patient had decreased exocrine pancreas function, and there were no hepatobiliary abnormalities that occur with GATA6 mutations. The presence of diabetes autoantibodies excluded type $2 \mathrm{DM}$ in our patient, although positive antibodies are frequently found in cases of type $2 \mathrm{DM}^{1{ }^{11}}$ Because the patient in this case presented with diabetic ketoacidosis, low insulin, and a low C-peptide level according to the blood glucose level, type $1 \mathrm{DM}$ was considered.

Congenital cytomegalovirus (CMV) infection can be indicated by findings such as preterm delivery, intrauterine growth retardation, microcephaly, chorioretinitis, hepatosplenomegaly, sensorineural hearing loss, hyperbilirubinemia, impaired liver function tests, and thrombocytopenia (characterized by petechiae and purpura through direct suppression of bone marrow megakaryocytes). ${ }^{12)}$ Congenital rubella infection can be associated with similar findings, including intrauterine growth retardation, cataracts, patent ductus arteriosus, hearing loss, microcephaly, thrombocytopenia, and severe fetal injury. Therefore, congenital CMV infection should be included in the differential diagnosis of patients with suspected congenital rubella infection.

In the present case, the patient's mother had a fever and a red rash on her face during pregnancy. From 3 months of age, the patient was followed by the Pediatric Cardiology Department for patent ductus arteriosus, and the case was finally diagnosed as type 1 diabetes due to congenital rubella infection, especially considering the finding that autoimmune type 1 DM develops in $12 \%-20 \%$ of cases with congenital rubella infection.

There are no immunoserological parameters that show a definite association between clinical findings and congenital rubella infection. Likewise, there is no biochemical or serological indication for this viral infection that is associated with immunodeficient type 1 diabetes, although it is known that the rubella virus infects pancreatic beta cells. A literature search revealed a 14-month-old patient who died of diabetic ketoacidosis and was diagnosed with congenital rubella infection. Insulinitis was discovered in the pathological examination of this patient's pancreas. ${ }^{13)}$ Rubella virus was isolated from the pancreatic tissue of 5 fetuses aborted at the 19th and 21 st week of gestation, but morphological abnormalities were not detected. ${ }^{14)}$ Postmortem pathologic examinations of 45 children diagnosed with DM secondary to congenital rubella infection revealed a normal pancreatic appearance in 43 patients, one case of the insulitis and one case of long-term type 1 diabetes-related pathological changes. ${ }^{15)}$ We can not perform a pancreatic histological examination in the present case because the procedure is considered too invasive. However, it would be valuable to show insulitis appearance for our case. 
Patients with congenital rubella infection usually present with cardiac involvement, hearing loss, eye manifestations, intrauterine growth restriction, microcephaly, behavioral problems and immunologic features, including islet cell surface antibodies with type 1 DM. Congenital rubella infection should be considered in diabetic patients who present with hearing loss, cardiac anomalies, and microcephaly.

\section{Ethical statement}

Written informed consent by our patient was obtained for publication of this case report.

\section{Conflict of interest}

No potential conflict of interest relevant to this article was reported.

\section{References}

1. Edlich RF, Winters KL, Long WB 3rd, Gubler KD. Rubella and congenital rubella (German measles). J Long Term Eff Med Implants 2005;15:319-28.

2. Andrade JQ, Bunduki V, Curti SP, Figueiredo CA, de Oliveira MI, Zugaib M. Rubella in pregnancy: intrauterine transmission and perinatal outcome during a Brazilian epidemic. J Clin Virol 2006;35:285-91.

3. Korkmaz HA, Aydin A, Arslan N. Presenting with 1solated hepatitis caused by congenital rubella infection due to maternal rubella vaccination. J Pediatr Infect 2015;9:38-41.

4. Larsson K, Elding-Larsson H, Cederwall E, Kockum K, Neiderud J, Sjöblad S, et al. Genetic and perinatal factors as risk for childhood type 1 diabetes. Diabetes Metab Res Rev 2004;20:429-37.

5. Ginsberg-Fellner F, Witt ME, Fedun B, Taub F, Dobersen
MJ, McEvoy RC, et al. Diabetes mellitus and autoimmunity in patients with the congenital rubella syndrome. Rev Infect Dis 1985;7 Suppl 1:S170-6.

6. Menser MA, Forrest JM, Honeyman MC, Burgess JA. Letter: Diabetes, HL-A antigens, and congenital rubella. Lancet 1974;2:1508-9.

7. Barrett TG, Bundey SE. Wolfram (DIDMOAD) syndrome. J Med Genet 1997;34:838-41.

8. Korkmaz HA, Demir K, Hazan F, Yıldız M, Elmas ÖN, Özkan B. Association of Wolfram syndrome with Fallot tetralogy in a girl. Arch Argent Pediatr 2016;114:e163-6.

9. Minton JA, Rainbow LA, Ricketts C, Barrett TG. Wolfram syndrome. Rev Endocr Metab Disord 2003;4:53-9.

10. Gong M, Simaite D, Kühnen P, Heldmann M, Spagnoli F, Blankenstein O, et al. Two novel GATA6 mutations cause childhood-onset diabetes mellitus, pancreas malformation and congenital heart disease. Horm Res Paediatr 2013;79:250-6.

11. Zaharieva ET, Velikova TV, Tsakova AD, Kamenov ZA. Prevalence of positive diabetes-associated autoantibodies among type 2 diabetes and related metabolic and inflammatory differences in a sample of the Bulgarian population. J Diabetes Res 2017;2017:9016148.

12. Nassetta L, Kimberlin D, Whitley R. Treatment of congenital cytomegalovirus infection: implications for future therapeutic strategies. J Antimicrob Chemother 2009;63:862-7.

13. Patterson K, Chandra RS, Jenson AB. Congenital rubella, insulitis, and diabetes mellitus in an infant. Lancet 1981;1:1048-9.

14. Smithells RW, Sheppard S, Marshall WC, Peckham C, De Prins F, Van Assche FA, et al. Congenital rubella and diabetes mellitus. Lancet 1978;311:439-40.

15. Jenson AB, Rosenberg HS, Notkins AL. Pancreatic isletcell damage in children with fatal viral infections. Lancet 1980;2:354-8. 